\title{
THE RELATIONSHIP BETWEEN SERUM CONCENTRATION OF TNF- $\alpha$ AND INSULIN SENSITIVITY IN RATS WITH DIABETES MELLITUS TYPE 2
}

\author{
Branka Djordjevići ${ }^{1}$ Tatjana Cvetković ${ }^{1}$, Tatjana Jevtović Stoimenov ${ }^{1}$, Milena Despotović1, \\ Andrej Veljković ${ }^{1}$ Jelena Bašić1, Aleksandra Veličkov², Jelena Milenković3, \\ Aleksandra Marjanović ${ }^{1}$, Milica Randjelović ${ }^{4}$, Vladana Stojiljković ${ }^{4}$, Dušan Sokolović ${ }^{1}$
}

\begin{abstract}
Diabetes and obesity are very common associated metabolic disorders that are linked to chronic inflammation. The development of insulin resistance is driven by multiple factors including an increase in levels of pro-inflammatory cytokines such as tumor necrosis factoralpha (TNF- $\alpha$ ). This study aimed to explore the links between TNF- $\alpha$-mediated inflammation, insulin sensitivity, and body weight gain in the rat model of type 2 diabetes mellitus (T2DM). The experiment was performed on 10 weeks old Wistar rats randomized into 2 groups. T2DM was induced by intraperitoneal injection of streptozotocin, administered 15 minutes after an intraperitoneal injection of nicotinamide. After 6 weeks, the animals were euthanized. Insulin and TNF- $\alpha$ were determined by using an enzyme-linked immunosorbent assay kit. Insulin sensitivity indices were calculated. The concentration of TNF- $\alpha$ was significantly higher in animals with T2DM when compared to controls $(p<0.001)$. Quantitative Insulin Sensitivity Check Index (QIUCKI) had significantly lower values in animals with T2DM when compared to controls ( $p<0.001)$, whereas values calculated for homeostatic model assessment of insulin resistance (HOMA-IR) were significantly higher $(p<0.001)$. TNF- $\alpha$ correlated positively with HOMA-IR $(r=0.562, p<0.01)$ and negatively with QIUCKI $(r=-0.332, p<0.05)$. Additionally, TNF- $\alpha$ correlated positively with specific rate of the body weight gain $(r=0.667, p$ $<0.01$ ) in the observed period. The results suggest that an increase in circulating TNF- $\alpha$ concentration might be associated with an increase in body weight gain and reduced insulin sensitivity in rats with T2DM.
\end{abstract}

Acta Medica Medianae 2021;60(3):42-47. obesity

Key words: type 2 diabetes mellitus, TNF- $\alpha$, insulin sensitivity, body weight,

\footnotetext{
${ }^{1}$ University of Niš, Faculty of Medicine, Department of

Biochemistry, Niš, Serbia

${ }^{2}$ University of Niš, Faculty of Medicine, Department of Histology

and Embryology, Niš, Serbia

${ }^{3}$ University of Niš, Faculty of Medicine, Department of

Pathophysiology, Niš, Serbia

${ }^{4}$ University Clinical Center Niš, Niš, Serbia
}

Contact: Branka Đorđević

81 Dr Zoran Djindjić Blvd., 18000 Niš, Serbia

E-mail: brankadjordjevic83@gmail.com

\section{Introduction}

Type 2 diabetes mellitus (T2DM) is an expanding global health problem accounting for around $90 \%$ of all cases of diabetes around the world. It is characterized by hyperglycemia, impaired insulin secretion, and reduced sensitivity to insulin/insulin resistance (1).

The development of insulin resistance is driven by multiple factors such as gluco-lipotoxicity, discoordinated glucose lowering response, reactive oxygen species (ROS) generation, epigenetics and an increase in levels of pro-inflammatory cytokines such as tumor necrosis factor-alpha (TNF- $\alpha$ ) (2).

TNF- $\alpha$ is synthesized as a transmembrane protein (tmTNF- $\alpha$ ) in several types of cells such as macrophages, monocytes, neutrophils, T-cells, adipocytes, and peripheral tissue cells $(2,3)$. The soluble form of TNF- $\alpha$ (STNF) is released through the action of matrix metalloproteinase, TNF- $\alpha$-converting enzyme (TACE). Both biologically active forms of TNF- $\alpha$ exert their effect through the receptors TNFR1 and TNF-R2 which activation causes cell death or cell survival respectively (4).

Obesity is a chronic inflammatory condition that has been linked to T2DM and insulin resistance (5). Obese individuals with T2DM have a higher level 
of circulating TNF- $\alpha$ when compared to lean individuals (6).

This study aimed to explore the links between TNF- $\alpha$ mediated inflammation, insulin sensitivity, and body weight gain in a rat model of T2DM, by testing the hypotheses that:

1) an increase in TNF- $\alpha$ leads to reduced insulin sensitivity, and

2) that both increases in TNF- $\alpha$ and reduced insulin sensitivity are in connection with an increase in body weight.

\section{Materials and methods}

\section{Experimental animals}

In this study, 10 weeks old Wistar rats were used. Animals were bred and housed in the vivarium of the Research Center for Biomedicine, Faculty of Medicine, University of Niš, at $22-24{ }^{\circ} \mathrm{C}$ with a $12-$ hour light cycle. Access to food and water was unrestricted in the course of the experiment. Animals consumed a standard laboratory rodent diet (AIN93M). The experiment was conducted under the Guide for the Care and Use of Laboratory Animals issued by the National Academy of Sciences, Washington, and the Book of Regulations for Work with Experimental Animals adopted by the Faculty of Medicine, University of Niš. The experimental protocol was approved by the Ethics Committee of the Faculty of Medicine, University of Niš (permit number 01-10204-3).

\section{Experimental procedure}

The animals were randomly divided into 2 groups ( $n=10)$, control (C), and T2DM. T2DM was induced by an intraperitoneal injection of a freshly prepared solution of streptozotocin (STZ) in citrate buffer (45 mg/kg; Sigma, USA), given 15 minutes after intraperitoneal injections of nicotinamide (NA, $110 \mathrm{mg} / \mathrm{kg}$; Sigma, USA) to the animals in the group T2DM (7). The animals in the group T2DM were injected with citrate buffer and saline respectively, according to the previously described procedure.

The diagnosis of T2DM was established by measuring glucose concentration in venous blood. Hyperglycemia was confirmed using an automated blood glucose meter Accu-Chek Performa (Roche). Blood was collected from the tail vein, after 2 and 8 hours fast, on the $3^{\text {rd }}$ and $7^{\text {th }}$ day after the STZ and NA injections. The cut-off values for the blood glucose were $>8.3 \mathrm{mmol} / \mathrm{L}$ and $>6.1 \mathrm{mmol} / \mathrm{L}$, after 2 and 8 hours fast, respectively.

After six weeks, the animals were euthanized by exsanguination after bilateral thoracotomy under deep anesthesia (Ketamidor, Richter Pharma AG; $100 \mathrm{mg} / \mathrm{kg}$, i.p.). The blood was taken by cardiac puncture (terminal). Before the animals were euthanized, the concentration of blood glucose was measured under the same conditions as at the beginning of the experiment.

\section{Animal measurements}

The body weight was measured weekly after night fasting.

The specific rate of body weight gain (SBWG) was calculated using formula $(\mathrm{g} / \mathrm{kg})=\Delta M M / M$, where $\triangle M M$ represents an increase in body weight in the observed period ( $\mathrm{dt}=\mathrm{t} 2-\mathrm{t} 1$ ) and $\mathrm{M}$ body weight at the time point $\mathrm{t} 1$.

\section{Sample Preparation}

Serum and plasma were separated by centrifugation (15 minutes at $3000 \mathrm{~g}$ ) and stored at $20{ }^{\circ} \mathrm{C}$. Na-EDTA was used as an anticoagulant.

\section{Determination of serum glucose}

Serum glucose levels were determined by using an enzymatic method on an automated clinical chemistry analyzer (Dimension RxL Max, Siemens, USA) using original reagents from Siemens Healthcare Diagnostics.

\section{Determination of serum insulin and TNF- $\alpha$}

Insulin levels were determined by using a commercially available rat enzyme-linked immunosorbent assay (ELISA) kit (Mercodia Rat Insulin ELISA, Uppsala, Sweden). TNF- $\alpha$ levels were determined by using a commercially available rat ELISA kit (Rat TNF- $\alpha$ ELISA Kit, Abcam Cambridge, UK).

\section{Calculation of insulin sensitivity indices}

Homeostatic model assessment of insulin resistance (HOMA-IR) was calculated assuming an average HOMA-IR of 1 in control young adult rats, analogous to the assumptions in humans (8). The equation used for HOMA-IR calculation was as follows HOMA-IR = (fasting glucose $(\mathrm{mg} / \mathrm{dl}) *$ fasting insulin $(\mu \mathrm{U} / \mathrm{ml})) / 2430(8)$. Quantitative insulin sensitivity check index (QUICKI) was calculated according to the original formula

QUICKI $=1 /[\mathrm{log}$ (fasting glucose $(\mathrm{mg} / \mathrm{dl})+$ $\log ($ fasting insulin $(\mu \mathrm{U} / \mathrm{ml})](8)$.

\section{Statistical analysis}

The data were expressed as mean \pm standard deviation. Statistical analysis was performed using the IBM $^{\circledR}$ SPSS $^{\circledR}$ Statistics 21.0. The KolmogorovSmirnov test was used to test the normality of distribution. Comparison of continuous variables was performed using a Student's t-test. The linear relationship between quantitative variables was determined using the Pearson test for parametric data. The level of significance for all statistical tests was set at $5 \%$. 


\section{Results}

Specific rate of body weight gain, non-fasting, fasting glucose, insulin levels and QUICKI and HOMA-IR values in the control and experimental rats are shown in Table 1. Specific rate of body weight gain (SBWG) was significantly higher in the T2DM group $(p<0.01)$. There were significant differences in both non-fasting (T2DM vs. C, p $<0.001$ ) and fasting glucose levels (DM vs. $C, p<0.001$ ) between the T2DM and the control group. Insulin levels did not differ between groups (T2DM vs. C, NS). Both QUICKI and HOMA-IR values were significantly different in group T2DM when compared to C (QUICKI, T2DM vs. C, p < 0.05; HOMA-IR, T2DM vs. $C, p<0.001)$.

Table 1. Specific rate of body weight gain, biochemical parameters of glucose metabolism and insulin sensitivity indices in healthy (C) and rats with type 2 diabetes mellitus (T2DM).

\begin{tabular}{|c|c|c|}
\hline & $\mathrm{C}$ & T2DM \\
\hline Specific rate of body weight gain ( $\mathrm{g} / \mathrm{kg}$ bw) & $0.12 \pm 0.02$ & $0.17 \pm 0.03 *$ \\
\hline Non-fasting glucose (mmol/l) & $6.53 \pm 0.75$ & $10.81 \pm 0.61 *$ \\
\hline Fasting glucose $(\mathrm{mmol} / \mathrm{l})$ & $4.82 \pm 0.19$ & $6.51 \pm 0.34 *$ \\
\hline Insulin $(\mu \mathrm{U} / \mathrm{ml})$ & $30.49 \pm 2.70$ & $33.58 \pm 3.54$ \\
\hline QUICKI & $0.46 \pm 0.01$ & $0.44 \pm 0.01 *$ \\
\hline HOMA-IR & $1.14 \pm 0.12$ & $1.64 \pm 0.19 *$ \\
\hline
\end{tabular}

Values are mean \pm standard deviation of the mean

Means with superscript differ significantly (Student's t-test), $p<0.05$
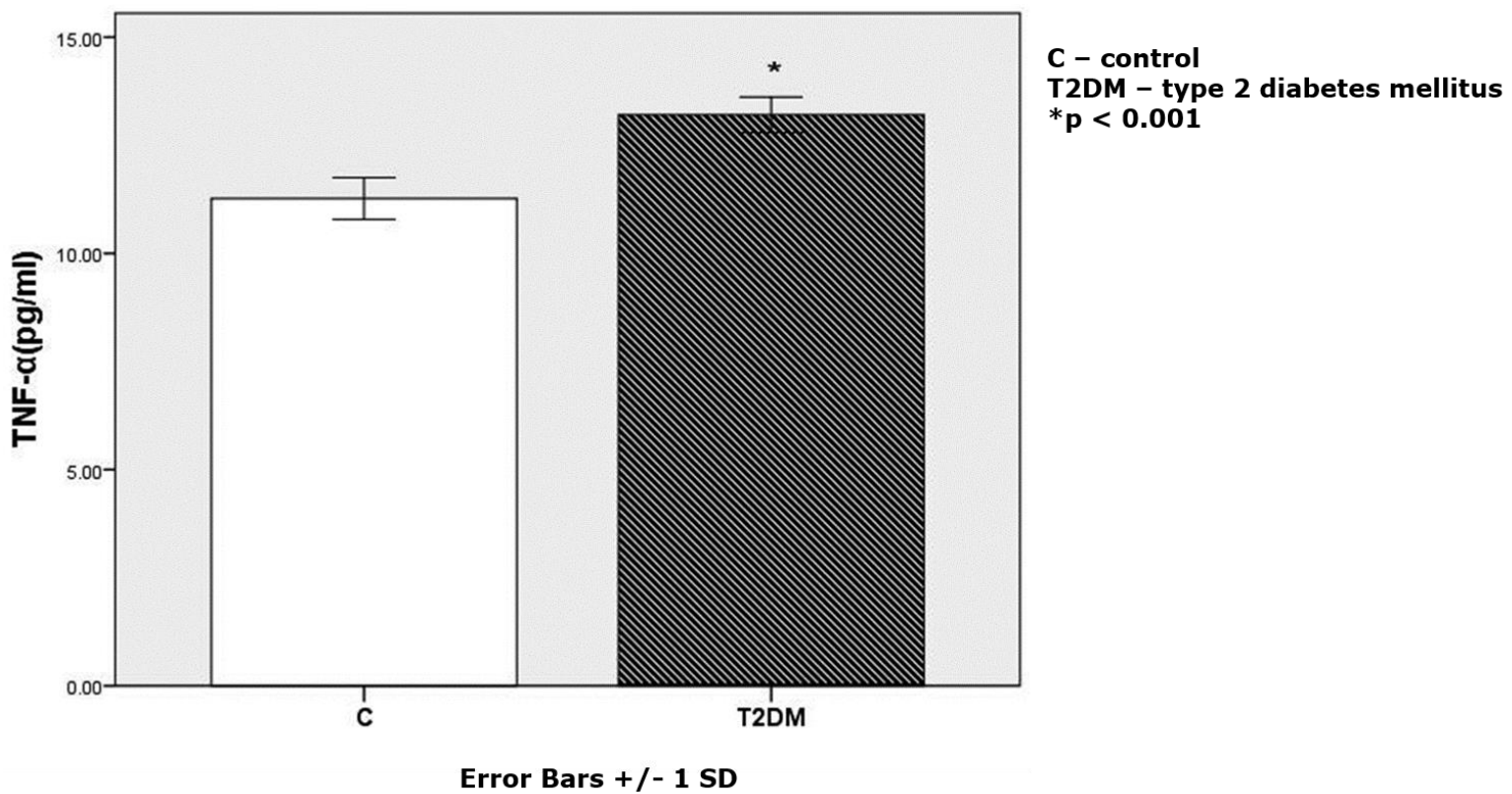

Figure 1. Circulating TNF- $\alpha$ concentration in animals with type 2 diabetes mellitus 
Table 2. Pearson correlation coefficient ( $r$ ) between TNF- $\alpha$, insulin sensitivity indices and specific rate of body weight gain (SBWG)

\begin{tabular}{||c|c|c|c|c|}
\cline { 2 - 5 } \multicolumn{1}{c|}{} & \multicolumn{2}{c|}{ TNF- $\alpha$} & \multicolumn{2}{c|}{ SBWG } \\
\cline { 2 - 5 } \multicolumn{1}{c|}{} & $\mathrm{r}$ & $\mathrm{P}$ & $\mathrm{r}$ & $\mathrm{P}$ \\
\hline \hline TNF- $\alpha$ & 1 & $\mathrm{~N} / \mathrm{A}$ & 0.667 & $<0.001$ \\
\hline HOMA-IR & 0.562 & $<0.001$ & 0.334 & 0.043 \\
\hline QUICKI & -0.332 & 0.03 & -0.335 & 0.024 \\
\hline
\end{tabular}

Compared to controls, the concentration of TNF- $\alpha$ (Figure 1) was also significantly higher in animals with T2DM (T2DM vs. C, p < 0.001).

There was negative correlation between serum TNF- $\alpha$ and QUICKI (Table 2) and positive correlation between TNF- $\alpha$ and HOMA-IR (Table 2). Specific body weight gain was correlated to TNF- $\alpha$, QUICKI, and HOMA-IR (Table 2).

\section{Discussion and conclusion}

Both T2DM and obesity are recognized as serious public health concerns with a significant impact on the quality of life. Moreover, concerning trends of rising prevalence have been recorded in high and low-income countries $(9,10)$.

Our first hypothesis was that animals with T2DM would have higher circulating TNF- $\alpha$ and reduced insulin sensitivity. The hypothesis was accepted since the circulating TNF- $\alpha$ levels found in animals with T2DM were higher when compared to healthy animals. There was a correlation between TNF- $\alpha$ levels and values of surrogate measures of insulin sensitivity, QUICKI, and HOMA-IR. Both serum TNF- $\alpha$ levels and values of QUICKI and HOMAIR were in correlation with the increase in body weight gain, although the correlation with surrogate measures of insulin sensitivity was found to be weak.

The animal model of T2DM used in this experiment is characterized by impairment in insulin secretion and reduced glucose tolerance caused by both metabolic and non-metabolic disturbances in pancreatic $\beta$ cells $(7,11)$. The severity of diabetes induced by STZ/NA application depends on the doses of STZ and NA given (11). Serum insulin levels in this study were not significantly different than levels measured in healthy controls, whereas diabetic animals had mild to moderate hyperglycemia.

In humans with T2DM increased levels of proinflammatory cytokines, such as TNF- $\alpha$ and IL- 6 , are found in the systemic circulation (12). Increased concentrations of TNF- $\alpha$ were reported previously in an animal model similar to the one used in this experiment (13). Hyperglycemia could trigger the release of TNF- $\alpha$ by peripheral monocytes and adipocytes (14). Additionally, the expression of TNF- $\alpha$ appears to be increased in adipose and muscle tissue of both obese rodents and humans (15). An increase in circulating TNF- $\alpha$ might be linked to hyperinsulinemia and insulin resistance in peripheral tissues in obese and diabetic humans $(2,16-18)$. This study reported a correlation between levels of circulating TNF- $\alpha$ and insulin sensitivity indexes. The indexes used exhibited good sensitivity and specificity and provided an easy and accurate measure of insulin sensitivity in rats (8). Besides, we observed an increase in circulating TNF- $\alpha$ which appears to be in correlation with the specific body weight gain in the observed 6-week period. A positive correlation between serum TNF- $\alpha$ and HOMA-IR in obese humans with T2DM has been reported recently (19). Increased production of TNF- $\alpha$ in adipose tissue could be related to the obesity-associated insulin resistance that leads to the development of T2DM (20).

TNF- $\alpha$-induced insulin resistance might be driven by the molecular mechanisms that involve the activation of Jun $\mathrm{N}$-terminal kinase (JNK) and nuclear factor kappa-light-chain-enhancer of activated $\mathrm{B}$ cells (NF-kB) pathway (2). By activating transcriptional factor NF-kB, TNF- $\alpha$ induces the apoptosis of pancreatic $\beta$-cells that might lead to insulin secretion suppression $(2,21)$. JNK phosphorylates IRS1 at Ser307, which inhibits insulin-stimulated tyrosine phosphorylation of IRS- 1 that might result in inhibition of insulin signaling $(2,21,22)$. Additionally, TNF- $\alpha$ reduces the expression of insulin-dependent glucose transporter type 4 (GLUT4) located in adipocytes and skeletal muscles (23).

In conclusion, an increase in circulating TNF- $\alpha$ might be associated with reduced insulin sensitivity and an increased body weight gain in rats with T2DM.

\section{Acknowledgments}

This study is realized within the Grant no. 451-03-9/2021-14/200113 of the Ministry of Science, Education and Technical Development of the Republic of Serbia. 


\section{References}

1. DeFronzo RA, Ferrannini E, Groop L, Henry RR, Herman WH, Holst Jj, et al. Type 2 diabetes mellitus. Nat Rev Dis Prim 2015;1:1-22. [CrossRef] [PubMed]

2. Akash MSH, Rehman K, Liaqat A. Tumor Necrosis Factor-Alpha: Role in Development of Insulin Resistance and Pathogenesis of Type 2 Diabetes Mellitus. ] Cell Biochem 2018;119:105-10. [CrossRef] [PubMed]

3. Hossain M, Faruque MO, Kabir G, Hassan N, Sikdar D, Nahar $Q$, et al. Association of serum TNF-a and IL-6 with insulin secretion and insulin resistance in IFG and IGT subjects in a Bangladeshi population. Int ] Diabetes Mellit 2010;2:165-8. [CrossRef]

4. Olmos G, Lladó J. Tumor necrosis factor alpha: A link between neuroinflammation and excitotoxicity. Mediators Inflamm. 2014;2014:861231.

[CrossRef] [PubMed]

5. Hamada D, Maynard R, Schott E, Drinkwater CJ, Ketz JP, Kates SL, et al. Suppressive Effects of Insulin on Tumor Necrosis Factor-Dependent Early Osteoarthritic Changes Associated with Obesity and Type 2 Diabetes Mellitus. Arthritis Rheumatol 2016;68:1392-402. [CrossRef] [PubMed]

6. Miyazaki Y, Pipek R, Mandarino LJ, DeFronzo RA. Tumor necrosis factor alpha and insulin resistance in obese type 2 diabetic patients. Int J Obes Relat Metab Disord 2003;27:88-94. [CrossRef] [PubMed]

7. Masiello P, Broca C, Gross R, Roye M, Manteghetti M, Hillaire-Buys D, et al. Experimental NIDDM: development of a new model in adult rats administered streptozotocin and nicotinamide. Diabetes 1998;47: 224-9. [CrossRef] [PubMed]

8. Cacho J, Sevillano J, de Castro J, Herrera E, Ramos MP. Validation of simple indexes to assess insulin sensitivity during pregnancy in Wistar and SpragueDawley rats. Am J Physiol Metab 2008;295:E1269-76. [CrossRef] [PubMed]

9. Khan MAB, Hashim MJ, King JK, Govender RD, Mustafa $\mathrm{H}$, Kaabi J Al. Epidemiology of Type 2 diabetes - Global burden of disease and forecasted trends. J Epidemiol Glob Health 2020;10:107-11. [CrossRef] [PubMed]

10. Hruby A, Hu FB. The Epidemiology of Obesity: A Big Picture. Pharmacoeconomics 2015;33(7):673-89. [CrossRef][PubMed]

11. Szkudelski T. Streptozotocin-nicotinamide-induced dia-betes in the rat. Characteristics of the experimental model. Exp Biol Med 2012;237:481-90. [CrossRef] [PubMed]
12. Das UN. Is there a role for bioactive lipids in the pathobiology of diabetes mellitus? Front Endocrinol (Lausanne) 2017;8:182. [CrossRef] [PubMed]

13. Palsamy $P$, Subramanian $S$. Ameliorative potential of resveratrol on proinflammatory cytokines, hyperglycemia mediated oxidative stress, and pancreatic $\beta$-cell dysfunction in streptozotocin-nicotinamide-induced diabetic rats. J Cell Physiol 2010;224:423-32. [CrossRef] [PubMed]

14. Gonzalez Y, Herrera MT, Soldevila G, Garcia-Garcia L, Fabián G, Pérez-Armendariz EM, et al. High glucose concentrations induce TNF-a production through the down-regulation of $\mathrm{CD} 33$ in primary human monocytes. BMC Immunol 2012;13:19. [CrossRef] [PubMed]

15. Saghizadeh M, Ong JM, Garvey WT, Henry RR, Kern $\mathrm{PA}$. The expression of TNFa by human muscle: Relationship to insulin resistance. J Clin Invest 1996; 97:1111-6. [CrossRef] [PubMed]

16. Hotamisligil GS. Inflammation and metabolic disorders. Nature 2006;444:860-7. [CrossRef] [PubMed]

17. Miyazaki $Y$, Pipek R, Mandarino $U$, DeFronzo RA. Tumor necrosis factor $a$ and insulin resistance in obese type 2 diabetic patients. Int J Obes Relat Metab Disord 2003;27:88-94. [CrossRef] [PubMed]

18. Swaroop JJ, Rajarajeswari D, Naidu JN. Association of TNF-a with insulin resistance in type 2 diabetes mellitus. Indian J Med Res 2012;135:127-30.

[CrossRef] [PubMed]

19. Alzamil H. Elevated Serum TNF-a Is Related to Obesity in Type 2 Diabetes Mellitus and Is Associated with Glycemic Control and Insulin Resistance. J Obes 2020;2020:5076858. [CrossRef] [PubMed]

20. Rajarajeswari D, Ramalingam K, Naidu JN. Tumor necrosis factor-alpha in the development of insulin resistance in type 2 diabetes mellitus. Int $\mathrm{J}$ Pharma Bio Sci 2011;2:B.352-B.357.

21. Rehman K, Akash MS. Mechanisms of inflammatory responses and development of insulin resistance: how are they interlinked? J Biomed Sci 2016;23(1):87. [CrossRef] [PubMed]

22. Rui L, Aguirre V, Kim JK, Shulman GI, Lee A, Corbould $A$, et al. Insulin/IGF-1 and TNF-alpha stimulate phosphorylation of IRS-1 at inhibitory Ser307 via distinct pathways. J Clin Invest 2001;107:181-9. [CrossRef] [PubMed]

23. Olson AL. Regulation of GLUT4 and Insulin-Dependent Glucose Flux. ISRN Mol Biol 2012;2012:1-12. [CrossRef] [PubMed] 


\title{
POVEZANOST KONCENTRACIJE TNF- $\alpha$ U SERUMU I INSULINSKE SENZITIVNOSTI KOD PACOVA SA DIJABETESOM MELLITUSOM TIP 2
}

\author{
Branka Đorđević1, Tatjana Cvetković1, Tatjana Jevtović Stoimenov ${ }^{1}$, Milena Despotović1, \\ Andrej Veljković1, Jelena Bašić ${ }^{1}$, Aleksandra Veličkov², Jelena Milenković3,

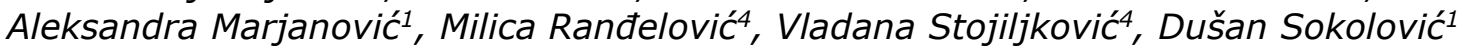

\author{
${ }^{1}$ Univerzitet u Nišu, Medicinski fakultet, Katedra za biohemiju, Niš, Srbija \\ ${ }^{2}$ Univerzitet u Nišu, Medicinski fakultet, Katedra za histologiju i embriologiju, Niš, Srbija \\ ${ }^{3}$ Univerzitet u Nišu, Medicinski fakultet, Katedra za patofiziologiju, Niš, Srbija \\ ${ }^{4}$ Univerzitetski klinički centar Niš, Niš, Srbija
}

Kontakt: Branka Đorđević

Bulevar dr Zorana Đinđića 81, 18000 Niš, Srbija

E-mail: brankadjordjevic83@gmail.com

Dijabetes melitus i gojaznost su metabolički poremećaji povezani sa hroničnom inflamacijom, koji se često javljaju u opštoj populaciji. Razvoj insulinske rezistencije povezan je sa mnogobrojnim faktorima, uključujući povećanje koncentracije proinflamatornih citokina, poput faktora nekroze tumora alfa (TNF- $\alpha$ ). Cilj ove studije bio je da ispita povezanost koncentracije TNF- $\alpha$, insulinske senzitivnosti i povećanja telesne mase na animalnom modelu dijabetesa melitusa tipa 2 (T2DM). Eksperiment je izveden na 10 nedelja starim Vistar pacovima nasumično podeljenim u 2 grupe. T2DM indukovan je intraperitonealnom injekcijom streptozotocina, primenjenom 15 minuta nakon intraperitonealne injekcije nikotinamida. Posle 6 nedelja, životinje su žrtvovane. Koncentracije insulina i TNF- $\alpha$ određene su korišćenjem komercijalnog enzimskog imunoeseja. Indeksi insulinske senzitivnosti određeni su preračunavanjem uz upotrebu odgovarajućih formula. Koncentracija TNF- $\alpha$ bila je značajno veća kod životinja sa T2DM u poređenju sa životinjama iz kontrolne grupe $(p<0,001)$. Kvantitativni indeks provere insulinske senzitivnosti (QIUCKI) imao je značajno niže vrednosti kod životinja sa T2DM u poređenju sa životinjama iz kontrolne grupe ( $p<0,001)$, dok su vrednosti izračunate za homeostatski model procene insulinske rezistencije (HOMA-IR) bile značajno veće $(p<0,001)$. TNF- $\alpha$ bio je u pozitivnoj korelaciji sa vrednostima HOMA-IR $(r=$ $0,562, p<0,01)$ i negativnoj korelaciji sa vrednostima QIUCKI $(r=-0,332, p<0,05)$. Pored toga, TNF- $\alpha$ je bio u pozitivnoj korelaciji sa specifičnim indeksom porasta telesne mase $(r=$ $0,667, p<0,01)$ u posmatranom periodu. Rezultati sugerišu na to da bi povećanje koncentracije TNF- $\alpha$ u cirkulaciji moglo biti povezano sa povećanjem telesne mase i smanjenom insulinskom senzitivnošću kod pacova sa T2DM.

Acta Medica Medianae 2021;60(3):42-47.

Ključne reči: dijabetes melitus tipa 2, TNF- $\alpha$, insulinska senzitivnost, telesna masa, gojaznost 